\title{
The Antibacterial Potential of Tannin from Mangosteen pericarp Extract against Lactobacillus casei
}

\author{
Bandaru Rahmatari ${ }^{1}$, Agus Subiwahjudi ${ }^{2}$ and Cecilia G. J. Lunardhi \\ ${ }^{1}$ Student of Dental Medicine \\ ${ }^{2}$ Teaching Staff of Conservation Dentistry Department \\ Faculty of Dental Medicine, Universitas Airlangga, Surabaya, Indonesia
}

\begin{abstract}
Background: Deep dentinal caries cannot defect the vitality of dental pulp. The microbial populations involved in dental caries are known to be highly complex and variable. Lactobacillus casei is one of the most common carious dentine bacteria. Tannin contained in mangosteen pericarp extract is known to have an antibacterial potency. Purpose: This study aims to determine the Minimum Inhibitory Concentration (MIC) and Minimum Bactericidal Concentration of tannin from mangosteen pericarp extract against Lactobacillus casei. Methods: This study is an experimental laboratory with a post-test only control group design. Tannin from mangosteen was extracted by $96 \%$ ethanol. Lactobacillus casei was diluted into several concentrations using the serial dilution method in the Brain Heart Infusion Broth (BHIB) medium and inserted in several reaction tubes. Every reaction tube was incubated for 24 hours. After being incubated, each concentration was taken and swabbed into Mueller Hinton in the petri dish. Then, every petri dish was incubated for 24 hours and colonies' growth was counted manually in the Colony Forming Unit (CFU). Results: Bacterial colonies' growth at a concentration of $1.56 \%$ was $90 \%$ less than the positive control group and there was no bacterial colonies growth at the concentration of 3.12\%. Conclusion: Tanin from mangosteen pericarp extract has an antibacterial effect against Lactobacillus casei. The MIC of tannin from mangosteen pericarp extract against Lactobacillus casei was at $1.56 \%$ and $M B C$ was at $3.12 \%$.
\end{abstract}

Keywords: Antibacterial potency; Tannin; Mangosteen pericarp extract; Lactobacillus casei

Correspondence: Bandaru Rahmatari, Student of Dental Medicine, Faculty of Dental Medicine, Universitas Airlangga. J1. Mayjen Prof. Dr. Moestopo 47, Surabaya, 60132 Indonesia. E-mail: bandaru_rahmatari@yahoo.com

\section{INTRODUCTION}

Dental caries is the process of dissolving enamel minerals as a result of disruption of the balance between the enamel and its surroundings caused by the formation of microbial acids and substrates so that the destruction of organic components appears. Bacteria can produce acids and cause the $\mathrm{pH}$ of the oral cavity to become acidic, and called as the demineralization process. However, the acidic atmosphere can be neutralized by saliva so that the $\mathrm{pH}$ rises again. This process is called remineralization. The result of an imbalance in the processes of demineralization and remineralization causes caries. ${ }^{1}$ Caries based on depth can be divided into superficial, medium, and profound. Media caries is caries that have hit the dentin but not more than half of the dentin. The dentin caries process is different than in enamel. Dentin has fewer minerals and has small tubules that are used as pathways for acid and mineral entry. Caries damage dentin faster than enamel. ${ }^{2}$

Microorganisms in the process of caries are very complex. Lactobacillus spp bacteria are the bacteria most commonly found in dentin caries which have acidogenic and aciduric properties, indicating that these bacteria predominate in dentin caries and correspond to the $\mathrm{pH}$ of dentin. ${ }^{3}$ Lactobacillus casei members, L. casei, L. paracasei, and L. rhamnosus, commonly found in dentin that is equal to $68 \% .^{4}$

Dentine caries can be remineralized if the cause is removed. Antimicrobials can be used as disinfectants to reduce the possibility of tissue infection. Chlorhexidine is used as a cavity disinfectant before curing. Chlorhexidine is effective against Lactobacilli but can cause staining on the tooth's coronal surface and cannot dissolve the remnants of tooth necrotic tissue.

Mangosteen (Garcinia mangostana L.) is a plant that comes from shady tropical forests in Southeast Asia. Mangosteen is a functional plant because most of these plants can be used as medicine. Various studies have shown that tannin active substances contained in mangosteen pericarp have antibacterial properties by coagulating or agglomerating bacterial protoplasms to form stable bonds with bacterial proteins. ${ }^{6}$ 
The purpose of this study was to determine the antibacterial power produced by the active substance of mangosteen pericarp extract (Garcinia mangostana L.) against the growth of Lactobacillus casei bacteria.

\section{MATERIALS AND METHODS}

This study is an experimental laboratory using a post-test only control group design. Samples from this study were Lactobacillus casei bacteria obtained from the Institute of Tropical Disease Hospital Universitas Airlangga.

Lactobacillus casei bacteria taken from the stock were inserted into a tube containing BHIB (Brain Heart Infusion Broth). Incubation was carried out for 1 x 24 hours at a temperature of $37^{\circ} \mathrm{C}$. After incubation, bacteria were standardized with $0.5 \mathrm{McF}$ arland (1.5 x $108 \mathrm{CFU} /$ $\mathrm{ml})$. Ten sterile tubes were provided and numbered from 1 to 10 . In tube No. 1 , the mangosteen pericarp extract tannin was put into a $100 \%$ concentration as much as 5 ml. Tubes number 2 to 10 were filled with BHIB media with $5 \mathrm{ml}$ each. In tube number 2 was given $5 \mathrm{ml}$ of $100 \%$ mangosteen pericarp extract. The volume of tube number 2 became $10 \mathrm{ml}$ and the final concentration was $50 \%$. The tannin concentration was diluted to the 8 th tube, the 9 th tube as a positive control containing BHIB media and bacteria, and the 10th tube as a negative control containing only BHIB media.

The tannin concentrations used as a test were $100 \%$, $50 \%, 25 \%, 12.5 \%, 6.25 \%, 3.125 \%, 1.562 \%, 0.781 \%$. Tubes 1 to 9 were each given $0.1 \mathrm{ml}$ of Lactobacillus casei bacteria. After that, a swab was conducted on Mueller-Hinton's media to get the MIC (Minimum Inhibitory Concentration) allegation. The results of the swab that did not show growth were made as a guess of MIC. $0.1 \mathrm{ml}$ of inoculum from 2 tubes above the alleged MIC, the suspected MIC tube, and 2 tubes under the estimated MIC then each leveled through a spread on the Mueller Hinton media to differentiate each treatment. The Minimum Inhibitory Concentration (MIC) and the Minimum Kill Concentration (MKC) were determined by counting the number of bacterial colonies that grow on Mueller Hinton's media so that it was manually expressed by a colony-forming unit (CFU) and compared
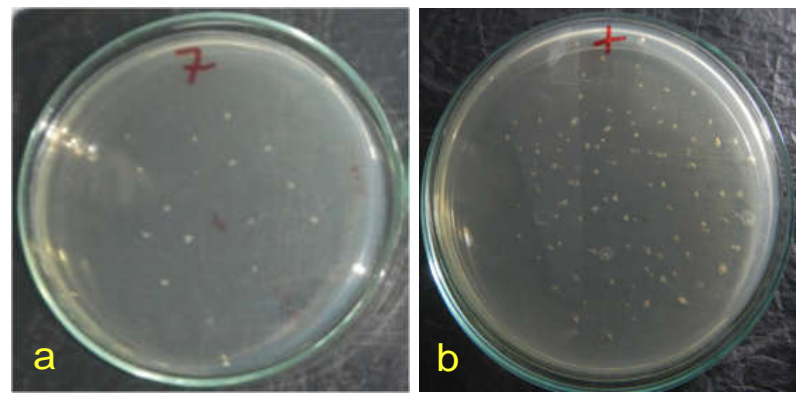

Figure 1. a. The result of the spread on Mueller Hinton agar media from a concentration of $1.56 \% \mathrm{~b}$. the results of the spread on the Mueller Hinton agar media from the control group $(+)$. with positive and negative controls. The calculation was repeated three times.

After calculating the number of bacterial colonies growing on Mueller Hinton agar media, data processing and analysis were conducted using SPSS with the Kolmogorov Smirnov normality test, Levene test for homogeneity tests, and Kruskal Wallis and Mann Whitney tests for nonparametric tests to see the significance of differences in the number of bacterial colonies between study groups.

\section{RESULTS}

This study was conducted using mangosteen pericarp tannin extract with concentration of $100 \%, 50 \%, 25 \%$, $12.5 \%, 6.25 \%, 3.12 \%, 1.56 \%, 0.78 \%$ as well as positive control and negative control. In this study, the results of the swab test on Mueller Hinton's media (Figure 1) showed that there was bacterial growth at the test concentrations of $1.56 \%$ and $0.78 \%$, while the concentrations of $3.12 \%$ and $6.25 \%$ did not indicate bacterial growth. Therefore, the concentration of $1.56 \%$ was used as a guideline in conducting bacterial cultivation to calculate the colony by taking a sample of 1 concentration under $1.56 \%$, consisting of $0.78 \%$ concentration and a concentration above $1.56 \%$, namely $3.12 \%$ concentration.

Table 1 show the results of study on the antibacterial power of mangosteen pericarp extract against Lactobacillus casei bacteria. The results of the colony count on Mueller Hinton's media in the study (Table 1) showed that at a concentration of $1.56 \%$ the average bacterial growth was 13 and at a concentration of $3.12 \%$ did not indicate the growth of test bacteria. This showed that the concentration of $1.56 \%$ was the MIC and the concentration of $3.12 \%$ was the MKC of mangosteen pericarp extract tannin against Lactobacillus casei bacteria.

To see the significance of the differences between the treatment groups, a mean comparison test was conducted with Kruskal Wallis test because the data were heterogeneous. $\mathrm{P}=0.027(\mathrm{p}<0.005)$ was obtained and showed that there were significant differences between the concentration groups and indicating differences in their effectiveness.

Table 1. Mean of the number of Lactobacillus casei colonies at various test concentrations

\begin{tabular}{lccc}
\hline $\begin{array}{c}\text { Tanin Concentration } \\
(\%)\end{array}$ & $\mathrm{N}$ & $\begin{array}{c}\text { X Number of } \\
\text { Colony (CFU/ml) }\end{array}$ & $\begin{array}{c}\text { X Number of } \\
\text { Colony }(\%)\end{array}$ \\
\hline 100 & 3 & 0 & 0 \\
50 & 3 & 0 & 0 \\
25 & 3 & 0 & 0 \\
12.5 & 3 & 0 & 0 \\
6.25 & 3 & 0 & 0 \\
3.12 & 3 & 0 & 10.7 \\
1.56 & 3 & 13 & 22.4 \\
0.78 & 3 & 27.3 & 100 \\
Control + & 3 & 121.7 & 0 \\
Control - & 3 & 0 & \\
\hline
\end{tabular}

Table 2. P-Value of the Mann Whitney test results

\begin{tabular}{llll}
\hline Concentration & Control $(+)$ & $3.12 \%$ & $1.56 \%$ \\
\hline Control $(+)$ & 0.037 & 0.037 & 0.046 \\
$3.12 \%$ & 0.046 & 0.034 & 0.034 \\
\hline $1.56 \%$ & &
\end{tabular}


To find out which data groups had significant differences in the number of colonies, the Mann Whiteny test was performed. A value would be considered to have a significant difference if the significance value was less than 0.05. Mann Whitney analysis test results between concentrations of $1.56 \%, 3.125 \%$, with a positive control group are as follows:

These results indicated that each concentration had a significant difference. These results indicated that there were differences in effectiveness between each concentration group.

\section{DISCUSSION}

This study was conducted to determine the antibacterial ability of mangosteen pericarp extract towards certain concentrations of Lactobacillus casei bacteria because the same study had never been done before. Mangosteen pericarp extract was isolated so tannin compounds were separated. Tannins have been proven to have antibacterial properties. In this study, mangosteen pericarp extract tannin was used with various concentrations, consisting of $100 \%$, $50 \%, 25 \%, 12.5 \%, 6.25 \%, 3.125 \%, 1.56 \%$, and $0.78 \%$ to see antibacterial ability against Lactobacillus casei bacteria.

The results showed that at a concentration of $0.78 \%$, the average growth in the number of bacterial colonies was 27.3 CFU / ml. Meanwhile, at a concentration of $1.56 \%$ the average growth of bacterial colonies was $13 \mathrm{CFU} / \mathrm{ml}$, resulting in a decrease in the number of bacteria from a concentration of $0.78 \%$ to a concentration of $1.56 \%$. At a concentration of $3.12 \%$, no bacterial growth was found.

This study was also proven by the Kruskal Wallis analysis test which showed a significant difference $(\mathrm{p}<0.05)$ and Mann Whitney which showed a significant difference between the groups tested and showed differences in effectiveness between the concentration groups. Therefore, it could be seen that mangosteen pericarp extract tannin had antibacterial power against Lactobacillus casei bacteria. The results of the study that showed a significant difference as mentioned, followed the existing theories saying that mangosteen pericarp extract tannin was proven to have antibacterial power.
The mechanism of mangosteen pericarp extract in inhibiting and killing the Lactobacillus casei bacteria is as follows: tannin can form complex bonds with proteins through non-specific forces such as hydrogen bonds and hydrophobic effects as well as covalent bond formation. It was also related to the inhibition of antibacterial enzymes such as cellulase pectinase and xylanase. Tannins can damage bacterial cell membranes that cause intracellular leakage. ${ }^{7}$

Thus it can be concluded that the mangosteen pericarp extract tannin concentration of $1.56 \%$ is the MIC of the Lactobacillus casei bacteria and the mangosteen pericarp extract tannin concentration of $3.12 \%$ is the MKC against the Lactobacillus casei bacteria.

It is hoped that further study on biocompatibility and toxicity will be made so that the effective concentration of mangosteen pericarp extract can be known. And it is expected that further study on the effectiveness of mangosteen pericarp extracts tannin as a material for developing cavity disinfecting materials will be conducted.

\section{REFERENCES}

1. Kidd, Edwina. 2005. Essential of Dental Caries. Third edition. New York : Oxford University Press

2. Roberson, Theodore, Heymann, Harald. 2012. Sturdevant's Art and science of operative dentistry. USA : Mosby, Inc

3. Love, Robert. 2004. Invasion of Dentinal Tubules by Root Canal Bacteria. Endodontic Topics, 9, 52-65. Blackwell Munkgaard

4. Byun Roy, Nadkarni M.A, Chhour Kim-Ly, Martin F.E, Jacques N.A, and Neil Hunter. 2004. Quantitative Analysis of Diverse Lactobacillus Species Present in Advanced Dental Caries. Journal Of Clinical Microbiology, Vol. 42, No. 7, p. 3132

5. Kaplowitz GJ, Cortell M. Chlorhexidine : A Multifunctional antimicrobial Drug. RDH, 2007;27:1-7

6. Pradipta I. S., Nikodemus T. W. dan Susilawati Y. 2004. Isolasi dan Identifikasi Senyawa Golongan Xanton dari Kulit Buah Manggis (Garcinia mangostana L.) hlm 64-77

7. Smullen J, Koutsou GA, Foster HA, Zumbé A, Storey DM. The antibacterial activity of plant extracts containing polyphenols against Streptococcus mutans. Caries Res. 2007;41(5):342-9. 